\title{
Formulasi Sediaan Gel Etosom Ekstrak Lamun (Enhalus acoroides) Sebagai Pencerah dan Pelembab Pada Kulit
}

\section{Formulation of Lamun Extract Gel Ethosomes (Enhalus acoroides) as Brightness and Moisturizing Agents on The Skin}

\author{
Muhammad Arif*, Faizatun, Anny Victor Purba \\ Magister Ilmu Kefarmasian Fakultas Farmasi Universitas Pancasila Jakarta \\ *E-mail: aptarif@gmail.com
}

DOI: https://doi.org/10.26874/jkk.v4i1.75

Received: 23 March 2021, Revised: 30 May 2021, Accepted: 30 May 2021, Online: 31 May 2021

\begin{abstract}
Abstrak
Lamun merupakan tanaman laut berbunga yang sering ditemukan di wilayah pesisir. Tanaman Lamun (Enhalus acoroides) mengandung senyawa fenol dan flavonoid yang dapat digunakan sebagai agen depigmentasi melalui penghambatan enzim tirosinase. Ekstrak etanol tanaman lamun diformulasikan ke dalam bentuk etosom untuk meningkatkan kemampuan penetrasi senyawa melalui stratum korneum. Penelitian ini bertujuan untuk memformulasi sediaan gel pelembab dari etosom ekstrak tanaman lamun (E. acoroides) pada kulit serta memiliki aktivitas menghambat enzim tirosinase sehingga dapat mencerahkan kulit. Etosom dibuat dengan menggunakan metode dingin sehingga dihasilkan formula yang baik dengan hasil karakterisasi ukuran partikel sebesar 216,1 nm yang diukur menggunakan Particle Size Analyzer (PSA). Etosom ekstrak lamun diformulasikan ke dalam bentuk gel dan dilakukan karakterisasi, indeks iritasi, dan uji aktivitas gel. Karakterisasi terdiri dari organoleptik, homogenitas, $\mathrm{pH}$, viskositas, dan daya sebar. Karakterisasi dilakukan terhadap gel yang disimpan pada suhu $4^{\circ} \mathrm{C}$, $27^{\circ} \mathrm{C}$, dan suhu $40^{\circ} \mathrm{C}$ selama dua bulan. Uji iritasi dilakukan secara topikal pada kelinci putih jantan. Hasil penelitian menunjukkan bahwa semua formula memiliki penampilan homogen yang baik dan berada pada rentang $\mathrm{pH} 5,38-5,80$. Hasil uji aktivitas menunjukkan gel etosom ekstrak lamun memiliki aktivitas melembapkan sebesar $17 \%$ selama satu bulan pemakaian sediaan, serta memiliki aktivitas menghambat enzim tirosinase dengan nilai $\mathrm{IC}_{50} 175,91 \mu \mathrm{g} / \mathrm{mL}$.
\end{abstract}

Kata kunci : Enhalus acoroides, etosom, enzim tirosinase, gel pelembab

\begin{abstract}
Seagrass is a flowering plant that lives in the sea and is found in almost all coastal areas. Seagrass (Enhalus acoroides) contains phenolic and flavonoid compounds, which are suitable as pigmentation agents due to tyrosinase inhibition. The ethanol extract from the seagrass plant is formulated into an ethosomal form to increase the compound's ability to penetrate the stratum corneum. This study aims to formulate a moisturizing gel preparation from the ethosome of seagrass plant extract (E. acoroides) on the skin that inhibits the tyrosinase enzyme so it can lighten the skin. Ethosomes were made using the cold process so that a good formula was made with the results of the characterization of the particle size of $216.1 \mathrm{~nm}$ measured using PSA. The seagrass extract ethosome was formulated into a gel and the properties, irritation index and gel activity test performed. The test of properties includes organoleptic, homogeneity, $\mathrm{pH}$, viscosity and dispersibility. The test was performed on gels that had been stored at $4^{\circ} \mathrm{C}, 27^{\circ} \mathrm{C}$ and $40^{\circ} \mathrm{C}$ for two months. The irritation test was performed topically on male white rabbits. The results showed that all formulas had a good homogeneous appearance and were in the $\mathrm{pH}$ range of 5.38 to 5.80. The results of the activity test showed that the etosome gel of the seagrass extract had a moisturizing activity of $17 \%$ for one month using the preparation and the tyrosinase enzyme had an IC 50 of $175.91 \mu \mathrm{g} / \mathrm{mL}$ inhibited.
\end{abstract}

Keywords: Enhalus acoroides, ethosomes, tyrosinase enzyme, moisturizing gel 


\section{Pendahuluan}

Lamun adalah tanaman laut berbunga yang sering ditemukan di wilayah pesisir [1]. Lamun merupakan satu dari sekian organisme yang mengalami evolusi konvergen dan berevolusi secara mandiri di waktu-waktu tertentu [2]. Lamun (E. acoroides) termasuk jenis terbanyak yang ditemukan di Indonesia dengan ukuran morfologi yang besar. Lamun jenis ini tumbuh subur di substrat lumpur. Menurut Kannan, kadar antioksidan total dari Lamun tersebut setara dengan 1 gram asam askorbat. Di negara maju, Lamun jenis ini sering digunakan dalam pencegahan berbagai penyakit degeneratif dan juga sebagai antioksidan [3]. Sedangkan di Maluku, Lamun ini daunnya dimanfaatkan untuk meningkatkan daya tahan tubuh terhadap penyakit degeneratif [4].

Qi dkk. berhasil mengisolasi 11 senyawa murni yang tergolong dalam golongan flavonoid dan steroid dari E. acoroides. Beberapa dari senyawa flavonoidnya terbukti toksik bagi larvalarva biota penempel, Bugula neritina [5]. Senyawa metabolit sekunder golongan flavonoid dapat menghambat aktivitas tirosinase seperti kaempferol, kuarsetin, kurarinon dan kushnol. E. acoroides juga dilaporkan mengandung senyawa bioaktif golongan fenolik yang berpotensi sebagai antioksidan [3].

Potensi ekstrak tanaman lamun sebagai pencerah dan pelembab kulit dapat diformulasi menjadi sediaan kosmetik. Stabilitas dan kemampuan berpenetrasi ke dalam lapisan kulit merupakan masalah yang sering dihadapi dalam sediaan kosmetik. Karena kulit merupakan lapisan penghalang yang efektif dalam penetrasi obat. Lapisan kulit paling luar, stratum korneum menjadi penghalang absorpsi zat aktif terutama bagi senyawa polar seperti polifenol. Salah satu strategi yang dapat digunakan untuk meningkatkan penetrasi senyawa melalui stratum korneum adalah dengan menggunakan sistem pembawa (carrier) yang berukuran nano [6].

Etosom dapat digunakan sebagai metode nano partikel yang mampu meningkatkan penetrasi senyawa ke dalam kulit. Etosom tersusun atas fosfolipid, alkohol konsentrasi tinggi dan air merupakan pembawa jenis vesikel halus dan lunak . Pada konsentrasi yang tepat dapat mengantarkan zat aktif secara transport pasif ke dalam lapisan kulit. Etosom memiliki manfaat mampu meningkatkan konsentrasi zat aktif di kulit, memungkinkan untuk molekul berukuran besar, secara luas diaplikasikan dalam kosmetik dan teknologi obat-obat herbal, dan dapat menjerap semua jenis molekul zat aktif seperti hidrofilik, lipofilik atau amfifilik. Selain itu biaya penyiapan etosom relatif lebih murah serta dapat dilakukan tanpa pemanasan (metode dingin) sehingga stabilitas bahan aktif lebih terjaga [7].

Kosmetik pencerah dan pelembab kulit umumnya dibuat dalam bentuk gel. Gel merupakan sediaan yang banyak memiliki kelebihan bila dibandingkan dengan sediaan topikal lainnya. Gel bila diaplikasikan pada kulit akan terasa ringan sehingga meningkatkan kenyamanan dalam penggunaannya. Sifat gel yang lunak, lembut, mudah dioleskan dan tidak menyisakan lapisan berminyak pada permukaan kulit menjadi alasan dalam pemilihan formulasi sediaan gel [7]. Beberapa keuntungan sediaan gel yaitu penyebarannya merata pada kulit, mudah dibersihkan, tidak menyebabkan lengket di kulit dan zat aktifnya terlepas dengan optimal [8]. Formulasi sediaan gel menggunakan etosom ekstrak lamun dapat memberikan hasil yang lebih baik.

\section{Metode Penelitian \\ Alat dan Bahan}

Alat-alat yang digunakan pada penelitian ini yaitu rotary vacum evaporator (Hanshin, China), pengaduk magnetik (Boeco MSH-300, Jerman), Particle Size Analyzer PSA (Litesizer ${ }^{\mathrm{TM}}$ Series Particle Analyzers), Timbangan Analitik dengan kepekaan 0,1 mg (labPRO DT224C), pH meter (OHAUS), dan alat gelas lainnya. Adapun bahan-bahan yang digunakan pada penelitian ini adalah Lamun, etanol 96\% (Brataco Chemical, Indonesia), propilen glikol, aqua demineralisata (Brataco, Indonesia).

\section{Pengambilan, Preparasi, dan Identifikasi Lamun}

Pengambilan Tanaman lamun dilakukan di perairan Pantai Batam, di jembatan 6 Balerang. Tanaman lamun yang telah dikumpulkan, terlebih dahulu dibersihkan dengan menggunakan air laut, bertujuan untuk menghilangkan kotoran lumpur yang menempel pada tanaman, selanjutnya dibersihkan kembali menggunakan air bersih untuk menghilangkan garam yang masih menempel. Sampel segar ini dimasukkan dalam wadah dan disimpan pada suhu $18^{\circ} \mathrm{C}$. Determinasi tanaman lamun dilakukan di Laboratorium Produktivitas dan Lingkungan Perairan (ProLing) Fakultas Perikanan dan Ilmu Kelautan Institut Pertanian Bogor (IPB). 


\section{Pembuatan ekstrak}

Tanaman Lamun dikeringkan di bawah sinar matahari selama 7 jam, mulai dari jam 08.00-15.00, selama 4 hari sehingga diperoleh kadar air berkisar antara 16,20\%-18,76\%, kemudian dihaluskan dan diperoleh bubuk sampel kering, dan ditimbang. Lamun yang telah dihaluskan kemudian ditimbang dan dilakukan proses ekstraksi dengan metode maserasi menggunakan pelarut etanol $96 \%$, diaduk dan didiamkan selama 1 kali 24 jam, selanjutnya disaring. Filtrat dilakukan penguapan dengan menggunakan alat vacum rotary evaporator. Ekstrak cair yang dihasilkan, selanjutnya dipanaskan di atas waterbath suhu $50^{\circ} \mathrm{C}$ sambil terus diaduk dan menghasilkan ekstrak kental Lamun.

\section{Pemeriksaan Karakteristik Ekstrak}

\section{a. Uji Organoleptis}

Pengujian organoleptis ini dilakukan untuk mengetahui bentuk fisik dari ekstrak (padat, serbuk, kental, cair), warna (hijau, kuning, coklat) dan bau (aromatik, tidak berbau).

\section{b. Perhitungan Nilai Rendemen}

Nilai rendemen ekstrak didapatkan dengan cara membagi bobot ekstrak kental dengan bobot awal simplisia. Dari perhitungan rendemen ini dapat diketahui nilai kesetaraan tiap gram ekstrak kental simplisia. Nilai rendemen dihitung dengan menggunakan persamaan 1 .

$$
\text { Rendemen ekstrak }(\%)=\frac{\text { bobot ekstrak kental }}{\text { bobot awal simplisia }} \times 100 \%
$$

(Persamaan 1)

\section{c. Skrining Fitokimia}

Skrining fitokimia disebut juga dengan penapisan fitokimia. Penapisan fitokimia bertujuan untuk menguji ada atau tidaknya kandungan alkaloid, saponin, tanin, flavonoid, gula pereduksi, triterpenoid dan steroid.

\section{d. Parameter Susut Pengeringan}

Dilakukan penimbangan ekstrak lamun sebanyak 1-2 gram dan dimasukkan ke dalam botol timbang yang sebelumnya telah dipanaskan pada suhu $105^{\circ} \mathrm{C}$ selama 30 menit. Sebelum ditimbang, terlebih dahulu ekstrak diratakan dalam botol timbang, hingga merupakan lapisan setebal 5-10 mm. Selanjutnya ekstrak lamun dimasukkan ke dalam Oven pada suhu $105^{\circ} \mathrm{C}$ hingga bobot tetap.

\section{e. Penetapan Kadar Abu Total}

Ekstrak sebanyak 2 g digerus, kemudian dimasukkan ke dalam krus silikat yang telah dipijarkan pada suhu $550^{\circ} \mathrm{C}$ dan ditara, diratakan. Pijarkan secara perlahan-lahan hingga arang habis, dinginkan, dan ditimbang. Jika cara ini arang tidak dapat dihilangkan, tambahkan air panas, saring melalui kertas saring bebas abu. Pijarkan sisa kertas dan kertas saring dalam krus yang sama. Filtrat dimasukkan ke dalam krus, diuapkan, pijarkan hingga bobot tetap, dan ditimbang. Batasan selisih penimbangan berikutnya hanya selisih sebanyak $5 \%$. Selanjutnya dihitung kadar abu terhadap bahan yang telah dikering anginkan.

\section{f. Penetapan Kadar Sari Larut Air}

Ekstrak lamun yang telah dikering anginkan ditimbang sebanyak $5 \mathrm{~g}$, maserasi selama 24 jam dengan $100 \mathrm{~mL}$ air-kloroform dibiarkan hingga 18 jam, disaring, $20 \mathrm{~mL}$ filtrat diuapkan hingga kering dalam cawan penguap yang telah ditara, residu dipanaskan pada suhu $105^{\circ} \mathrm{C}$ hingga bobot tetap.

\section{g. Penetapan Kandungan Total Fenol}

Ekstrak lamun sebanyak $100 \mathrm{mg}$ dilarutkan sampai $10 \mathrm{~mL}$ dengan aquades sehingga diperoleh konsentrasi $10 \mathrm{mg} / \mathrm{mL}$. Pada larutan konsentrasi $10 \mathrm{mg} / \mathrm{mL}$ dipipet $1 \mathrm{~mL}$ dan diencerkan dengan aquades hingga $10 \mathrm{~mL}$ dan diperoleh konsentrasi ekstrak $1 \mathrm{mg} / \mathrm{mL}$. Ekstrak sebanyak 0,2 mL dipipet, ditambahkan 15,8 mL aquades dan $1 \mathrm{~mL}$ reagen Folin-Ciocalteu lalu dikocok dan didiamkan selama 8 menit kemudian ditambahkan $3 \mathrm{~mL} \mathrm{Na}_{2} \mathrm{CO}_{3} 10 \%$ ke dalam campuran. Selama 2 jam larutan didiamkan pada suhu kamar. Diukur serapannya dengan menggunakan spektrofotometer UV-Vis pada panjang gelombang maksimum $765 \mathrm{~nm}$. Dilakukan 3 (tiga) kali pengulangan sehingga diperoleh kadar fenol di mana satuan hasilnya didapat sebagai $\mathrm{mg}$ ekuivalen dalam sampel segar [9].

\section{h. Flavonoid Total}

Pengukuran flavonoid total menggunakan metode kolorimetrik dengan aluminium klorida $\left(\mathrm{AlCl}_{3}\right)$. Metode ini menggunakan kuersetin kemurnian 98\% sebagai pembanding pada kurva kalibrasi. $10 \mathrm{mg}$ kuersetin dilarutkan dalam etanol $80 \%$ dan diencerkan sampai 25,50 dan 100 mikrogram $/ \mathrm{mL}$. Larutan standar pengenceran $(0,5 \mathrm{ml})$ dipisahkan dan dicampur dengan 1,5 ml dari etanol 95\%,0,1 $\mathrm{mL} \mathrm{AlCl}_{3}$, $0,10 \mathrm{~mL}$ dari Potasium asetat $1 \mathrm{M}$ dan $2,80 \mathrm{~mL}$ 
aquades. Kemudian diinkubasi selama 30 menit, serapan campuran diukur pada Panjang gelombang $415 \mathrm{~nm}$.

\section{Pembuatan Etosom Ekstrak Lamun}

Pembuatan etosom menggunakan metode dingin. Dalam metode ini fosfatidilkolin dilarutkan dengan etanol sebagai campuran 1, ekstrak dilarutkan dengan etanol sebagai campuran 2. Campuran fosfatidilkolin dan campuran ekstrak digabungkan menjadi satu kemudian di tambah dengan etanol sampai tanda batas dalam wadah tertutup pada suhu kamar, dilakukan pengadukan secara terus-menerus menggunakan stirrer selama 10 menit. Selanjutnya, campuran ini dipanaskan pada suhu $30^{\circ} \mathrm{C}$ menggunakan tangas air. Kemudian memanaskan air hingga suhu $30^{\circ} \mathrm{C}$ dalam wadah terpisah, ditambahkan ke dalam campuran sebanyak $10 \mathrm{~mL}$. Dilakukan pengadukan selama 5 menit dalam bejana tertutup. Ukuran partikel dan gelembung dari pembuatan etosom dapat diperkecil sesuai keinginan dengan penggunaan sonikasi bath [10].

\section{Optimasi Etosom Ekstrak Lamun}

Pada penelitian ini dibuat formulasi etosom yang mengandung ekstrak tanaman lamun. Variabel yang akan digunakan pada desain optimasi formula etosom ekstrak tanaman lamun adalah membandingkan pengaruh variasi konsentrasi lesitin (fosfatidikolin) yang digunakan. Perbandingan yang akan digunakan seperti pada Tabel 1 .

Tabel 1. Optimasi etosom dari ekstrak tanaman lamun

\begin{tabular}{ccccc}
\hline Nama Bahan & F1 & F2 & F3 & F4 \\
\hline Ekstrak Tanaman & 2 & 2 & 2 & 2 \\
Lamun $(\mathrm{g})$ & & 2 & 2,5 & 3 \\
Fosfatidikolin $(\mathrm{g})$ & 1 & 20 & 20 & 20 \\
Etanol $(\mathrm{mL})$ & 20 & 20 & & \\
Propilen glikol & 1 & 1 & 1 & 1 \\
$\quad(\mathrm{~mL})$ & & 100 & 100 & 100 \\
Air $(\mathrm{mL})$ & 100 & &
\end{tabular}

\section{Pembuatan Gel Pelembab}

\section{a. Pembuatan Basis Gel}

Kembangkan Carboxy Methyl Cellulose (CMC) dalam aquadest yang telah dipanaskan sebanyak 20 kalinya didalam beaker glass. Tambahkan phenoxyetanol dalam mortir dan ditambahkan gliserin, diaduk sampai homogen. Hasil pengembangan CMC ditambahkan dalam campuran, kemudian dilakukan pengadukan secara terus-menerus sehingga diperoleh massa gel yang berbentuk transparan. Sisa aquadest ditambahkan ke dalam campuran, dan diaduk sampai didapatkan sediaan gel yang homogen.

\section{b. Pengujian Stabilitas Fisik Sediaan Pelembab Gel}

- Uji Organoleptis. Uji organoleptis gel meliputi uji warna, bau dan konsistensi gel untuk mengetahui secara fisik keadaan gel. Pemeriksaan organoleptis dilakukan untuk mendeskripsikan warna, bau dan konsistensi dari sediaan gel yang sudah bercampur dengan basis, sediaan yang dihasilkan sebaiknya memiliki warna yang menarik, bau yang menyenangkan dan kekentalan yang cukup agar nyaman dalam penggunaan. Pengujian dilakukan setelah sediaan gel dibuat dalam satu hari [8].

- Uji Homogenitas Gel. Pengujian homogenitas sediaan gel dengan cara dioleskan pada kaca arloji, setelah itu dilakukan pengamatan.

- Uji Viskositas Gel. Pengukuran nilai viskositas sediaan gel dilakukan dengan menggunakan alat viscometer. Langkah awal rotor dipasang pada viskoseter dengan cara menguncinya berlawanan arah dengan jarum jam. Wadah (cup) diisi sampel gel yang akan diuji, setelah itu tempatkan rotor tepat berada ditengah-tengah wadah yang berisi gel, kemudian hidupkan alat. Rotor akan berputar dan amati jarum penunjuk viskositas yang bergerak menuju kekanan, kemudian setelah stabil viskositas dibaca dan diamati pada skala dari rotor yang digunakan [11].

- Uji Daya Sebar Gel. Pengujian dilakukan dengan menggunakan sepasang cawan petri, anak timbang gram dan stopwatch kemudian dilakukan dengan cara menimbang 0,5 g gel, diletakkan dengan kaca yang lainnya, diletakkan kaca tersebut di atas massa gel dan dibiarkan 1 menit. Diameter gel yang menyebar (dengan mengambil panjang rata-rata diameter dari beberapa sisi) diukur, kemudian ditambahkan $200 \mathrm{~g}$, sebagai bahan tambahan, diamkan selama 1 menit, kemudian amati dan dicatat diameter gel 
yang menyebar seperti sebelumnya. Pengujian dilakukan setelah sediaan gel dibuat dalam satu hari [8].

- Uji pH Gel. Uji ini dilakukan dengan menggunakan alat $\mathrm{pH}$ meter. Timbang 1 gram sediaan kemudian encerkan dengan aquadest hingga $10 \mathrm{~mL}$. Sediaan uji diambil dan ditempatkan pada tempat sampel $\mathrm{pH}$ meter, amati hasil $\mathrm{pH}$ yang ditunjukkan dengan indikator $\mathrm{pH}$ meter stabil dan menunjukkan nilai $\mathrm{pH}$ yang konstan [12].

- Uji Iritasi. Pada penelitian ini dilakukan pengujian iritasi primer. Pengujian iritasi dilakukan terhadap hewan uji kelinci jantan untuk mengetahui tingkat keamanan apakah gel etosom ekstrak lamun menyebabkan iritasi atau tidak.

\section{Uji Aktivitas Penghambatan Enzim Tirosinase Gel Etosom Ekstrak Lamun Secara In Vitro}

Gel etosom ekstrak lamun sejumlah $400 \mathrm{mg}$ dilarutkan dalam $5 \mathrm{~mL}$ etanol $96 \%$ sehingga diperoleh konsentrasi $20.000 \mu \mathrm{g} / \mathrm{mL}$. Dilakukan sonikasi terhadap larutan uji selama 15 menit, dilakukan penyaringan untuk memperoleh hasil yang optimal, lalu pipet sebanyak 2,5 mL, masukkan ke dalam labu ukur $5 \mathrm{~mL}$. Cukupkan volume dengan larutan dapar fosfat $\mathrm{pH}$ 6,8 hingga diperoleh konsentrasi larutan ekstrak $10.000 \mu \mathrm{g} / \mathrm{mL}$ demikian seterusnya sehingga diperoleh konsentrasi larutan ekstrak 500, 400, 300, 200 dan $100 \mu \mathrm{g} / \mathrm{mL}$.

\section{Uji efektivitas Pelembab}

Masing-masing subyek penelitian diberikan 2 jenis gel yaitu 1 buah gel kontrol (yang berkode: A-kanan) dan 1 buah gel uji (yang berkode B-kiri). Selain itu masing-masing subyek diberikan 2 buah plat plastik berukuran $10 \times 15 \mathrm{~cm}$. Plat plastik berkode A untuk dipakai di lengan atas sebelah kanan dan berkode B untuk di pakai di lengan atas sebelah kiri. Masing-masing plat tersebut sudah diberikan tanda batas dan dilubangi untuk area pengaplikasian gel seluas $6 \times 6 \mathrm{~cm}$. Pada subyek akan diaplikasikan gel $\mathrm{A}$ pada lengan atas sebelah kanan dan gel B pada lengan atas sebelah kiri setiap hari pada waktu/jam yang sama. Pengamatan ini dilakukan pada hari ke 14 dan 28.

\section{$3 \quad$ Hasil dan Diskusi}

\section{Pengambilan, Preparasi, dan Identifikasi Lamun}

Pengambilan tanaman lamun dilakukan di perairan Pantai Batam, yang berada di bawah jembatan 6 Balerang. Tanaman lamun yang telah dikumpulkan terlebih dahulu dibersihkan dengan menggunakan air laut untuk menghilangkan kotoran lumur yang menempel pada tanaman lamun, selanjutnya dibersihkan kembali dengan menggunakan air mengalir yang bersih untuk menghilangkan garam yang masih menempel. Tanaman lamun yang merupakan sampel segar dimasukkan dalam kantung plastik kemudian disimpan pada suhu $18^{\circ} \mathrm{C}$. Sampel segar sebanyak $10 \mathrm{~kg}$ kemudian dikering dengan sinar matahari selama 7 jam, mulai dari 08.00-15.00 selama 4 hari, kemudian sampel kering tanaman lamun dihaluskan sehingga diperoleh bubuk sampel kering sebanyak 780 gram. Determinasi tanaman lamun ini dilakukan di Laboratorium Produktivitas dan Lingkungan Perairan (ProLing) Fakultas Perikanan dan Ilmu Kelautan Institut Pertanian Bogor (IPB) dengan mengacu kepada El Shaffai A (2011), Kuo \& den Hartog (2001) dan Lanyon J, (1986). Hasil dari determinasi tanaman yang dilakukan yaitu tanaman lamun yang diperoleh memiliki spesies Enhalus acoroides.

\section{Pembuatan ekstrak}

Proses Ekstraksi senyawa aktif dari sampel kering tanaman Lamun (E. acoroides) dilakukan secara maserasi, yaitu dengan cara perendaman di dalam pelarut etanol $96 \%$ pada suhu ruang. Ekstrak lamun yang diperoleh dari hasil maserasi dipisahkan dari pelarut dengan menggunakan alat rotary evaporator, hingga diperoleh ekstrak kental sebanyak 142,33 gram.

\section{Hasil pemeriksaan Karakterisasi Ekstrak Etanol Tanaman Lamun \\ a. Hasil Organoleptik \\ Hasil organoleptik terhadap ekstrak etanol} tanaman Lamun diperlihatkan dalam Tabel 2. Berdasarkan hasil organoleptik, ekstrak memiliki viskositas yang cukup tinggi terlihat dari kekentalannya, berwarna hijau, memiliki bau yang khas, dan berasa pahit. 
Tabel 2. Hasil pengujian organoleptik ekstrak etanol tanaman lamun

\begin{tabular}{cc}
\hline Parameter uji & Hasil \\
\hline Bentuk & Ekstrak kental \\
Warna & Hijau \\
Bau & Khas \\
Rasa & Agak pahit \\
\hline
\end{tabular}

b. Hasil Perhitungan Nilai Rendemen Ekstrak Perhitungan nilai rendemen dari ekstrak menggunakan persamaan 2 dengan rincian data pada Tabel 3.

$$
\text { Rendemen ekstrak }(\%)=\frac{142,33}{663,3} \times 100 \%=21,45
$$

(persamaan 2)

Nilai rendemen ekstrak sebanyak 21,45\%. Nilai rendemen yang dihasilkan tidak bergantung terhadap banyaknya simplisia yang digunakan pada saat penelitian, melainkan kondisi alamiah dari senyawa yang terkandung di dalam tanaman itu sendiri.

Tabel 3. Hasil ekstrak etanol tanaman lamun

\begin{tabular}{ccccc}
\hline $\begin{array}{c}\text { Bobot } \\
\begin{array}{c}\text { Tanaman } \\
\text { Lamun } \\
(\mathbf{g})\end{array}\end{array}$ & $\begin{array}{c}\text { Volume } \\
\text { Etanol } \\
\mathbf{9 6 \%} \\
(\mathbf{L})\end{array}$ & $\begin{array}{c}\text { Bobot } \\
\text { Ekstrak } \\
(\mathrm{g})\end{array}$ & $\begin{array}{c}\text { Rendemen } \\
(\boldsymbol{\%})\end{array}$ & $\begin{array}{c}\text { DER } \\
\text { Native }\end{array}$ \\
\hline $\mathbf{6 6 3 , 3}$ & 15 & 142,33 & 21,45 & 4,66 \\
\hline
\end{tabular}

\section{c. Hasil Skrining Fitokimia}

Pengujian fitokimia ini dilakukan untuk mengetahui seberapa banyak senyawa metabolit sekunder yang ada di dalam ekstrak etanol tanaman lamun.

Tabel 4. Hasil skrining fitokimia ekstrak etanol tanaman lamun

\begin{tabular}{cc}
\hline Parameter Uji & Hasil \\
\hline Alkaloid & - \\
Saponin & + \\
Tannin & - \\
Fenolik & + \\
Flavonoid & + \\
Triterpenoid & + \\
Steroid & + \\
\hline
\end{tabular}

Dari hasil pengujian fitokimia ekstrak yang dilakukan, kandungan senyawa metabolit sekunder yang terdapat di dalam ekstrak etanol tanaman lamun berupa saponin, fenolik, flavonoid, triterpenoid dan steroid. Hasil metabolit sekunder ekstrak tanaman lamun dapat dilihat pada Tabel 4.

\section{d. Parameter Susut Pengeringan}

Hasil pengukuran nilai parameter susut pengeringan dari ekstrak etanol tanaman lamun sebesar $12,34 \%$. Pengukuran susut pengeringan ini dilakukan selain untuk menghindari cepatnya pertumbuhan mikroba dan jamur dalam ekstrak juga untuk mempertahankan kualitas dari ekstrak yang digunakan [13].

\section{e. Kadar Abu Total}

Penentuan kadar abu ini bertujuan untuk memberikan gambaran kandungan mineral baik secara internal maupun eksternal yang berasal dari proses awal sampai terbentuknya ekstrak. Yaitu dengan cara ekstrak lamun dipanaskan hingga senyawa-senyawa organik yang terkandung didalamnya beserta turunannya terdestruksi dan menguap sampai hanya unsur mineral dan anorganik saja. Dari hasil penelitian diperoleh kadar abu total ekstrak diperoleh sebesar 2,77\%.

\section{f. Kadar Sari Larut Air}

Pengujian kadar senyawa terlarut dalam air dilakukan untuk mengetahui tingkat kepolaran dari ekstrak tanaman lamun. Ekstrak etanol tanaman lamun memiliki kecenderungan bersifat polar. Tingkat kepolaran hasil dari ekstraksi ini dapat digunakan untuk mengidentifikasi senyawasenyawa spesifik yang terdapat di dalam ekstrak tanaman lamun. Hasil pengukuran kadar sari larut air dari ekstrak tanaman lamun sebesar $21,73 \%$.

\section{g. Penetapan Kandungan Fenol Total}

Nilai konsentrasi dari larutan sampel uji dapat ditentukan dengan menggunakan kurva kalibrasi dengan cara mengukur nilai absorbansi sampel kemudian kadar total fenolik dihitung dengan menggunakan persamaan regresi linier. Kandungan total fenolik dalam ekstrak etanol tanaman Lamun sebesar 22,04 \%. Hasil pengukuran disajikan pada tabel 5 .

\section{h. Penetapan Kandungan Flavonoid Total}

Kandungan flavonoid total dari ekstrak etanol Lamun diperlihatkan pada Tabel 6. 
Tabel 5. Kadar Total Fenol Ekstrak Etanol Tanaman Lamun

\begin{tabular}{ccccc}
\hline Kode Sampel & $\begin{array}{c}\text { Berat Ekstrak } \\
(\mathbf{m g})\end{array}$ & Absorbansi & \multicolumn{2}{c}{ Kadar Fenol } \\
& 0,050 & 0,677 & 22,37 & $\mathbf{m g} / \mathbf{1 0 0} \mathbf{g}$ \\
\hline A1 & 0,053 & 0,683 & 22,57 & 22366,67 \\
A2 & 0,059 & 0,641 & 21,17 & 21166,67 \\
A3 & Rata-rata kadar fenol & & 22,04 & 22033,37 \\
\hline
\end{tabular}

Tabel 6. Kadar Total Flavonoid Ekstrak Etanol Tanaman Lamun

\begin{tabular}{ccccc}
\hline $\begin{array}{c}\text { Kode } \\
\text { sampel }\end{array}$ & $\begin{array}{c}\text { Berat ekstrak } \\
(\mathbf{m g})\end{array}$ & Absorbansi & \multicolumn{2}{c}{ Kadar Flavonoid } \\
\cline { 4 - 5 } B1 & 0,318 & 0,216 & $\%, 78$ & $\mathrm{mg} / 100 \mathrm{~g}$ \\
B2 & 0,318 & 0,213 & 5,72 & 5786,88 \\
B3 & 0,318 & 0,216 & 5,78 & 578,40 \\
\hline \multicolumn{3}{c}{ Rata-rata kadar flavonoid } & 5,76 & 5766,88 \\
\hline
\end{tabular}

\section{Etosom Ekstrak Lamun}

Etosom ekstrak lamun telah berhasil dibuat dengan metode dingin. Metode ini dilakukan dengan cara lesitin (fosfatidikolin) dilarutkan dalam pelarut etanol pada bejana tertutup, kemudian diwadah terpisah ekstrak lamun dilarutkan dengan menggunakan etanol, ekstrak etanol lamun dan fosfatidilkolin dicampur kemudian dilakukan pengadukan dengan menggunakan magnetic stirrer selama 15 menit pada kecepatan $750 \mathrm{rpm}$. Campuran dipanaskan dengan suhu $30^{\circ} \mathrm{C}$ menggunakan magnetic stirrer dan ditambah air dengan suhu $30^{\circ} \mathrm{C}$. Campuran tersebut diaduk dengan menggunakan magnetic stirrer selama 10 menit, sehingga membentuk etosom yang baik. Penelitian ini melakukan optimasi pada 4 formula dengan membandingkan kadar lesitin untuk tiap-tiap formula. Formula dan hasil optimasi disajikan pada Tabel 7.

Tabel 7. Rincian formula dan Hasil karakterisasi etosom ekstrak lamun

\begin{tabular}{|c|c|c|c|c|}
\hline \multirow[t]{2}{*}{ Bahan } & \multicolumn{4}{|c|}{ Jumlah (\%) } \\
\hline & Formula I & Formula II & Formula III & Formula IV \\
\hline Lesitin & 1 & 2 & 2,5 & 3 \\
\hline Ekstrak Lamun & 2 & 2 & 2 & 2 \\
\hline Alkohol & 20 & 20 & 20 & 20 \\
\hline Propilen glikol & 1 & 1 & 1 & 1 \\
\hline $\begin{array}{c}\text { Air } \\
\text { Karakterisasi }\end{array}$ & Ad $100 \mathrm{~mL}$ & Ad $100 \mathrm{~mL}$ & Ad $100 \mathrm{~mL}$ & Ad $100 \mathrm{~mL}$ \\
\hline Organoleptik & $\begin{array}{c}\text { Larutan } \\
\text { berwarna Hijau }\end{array}$ & $\begin{array}{c}\text { Larutan } \\
\text { berwarna Kuning } \\
\text { kehijauan }\end{array}$ & $\begin{array}{c}\text { Larutan } \\
\text { berwarna Kuning } \\
\text { kehijauan }\end{array}$ & $\begin{array}{l}\text { Larutan } \\
\text { berwarna } \\
\text { Kuning }\end{array}$ \\
\hline $\begin{array}{l}\text { Ukuran partikel } \\
\text { (nm) }\end{array}$ & 241,2 & 703,4 & 431,4 & 216,1 \\
\hline
\end{tabular}

Formula IV dengan ukuran partikel 216,1 nm di pilih untuk dilakukan uji karakteristik lanjutan berupa uji zeta potensial dan uji TEM (Transmission Electron Microscope). Nilai zeta potensial etosom ekstrak tanaman lamun sebesar -
$19.23 \mathrm{mV}$, nilai ini menunjukkan hasil yang cukup baik dan akan menghasilkan bentuk koloid yang lebih stabil karena mampu menolak agregasi. Analisa menggunakan TEM diperoleh bentuk 
morfologi yang baik seperti yang ditampilkan pada Gambar 1.
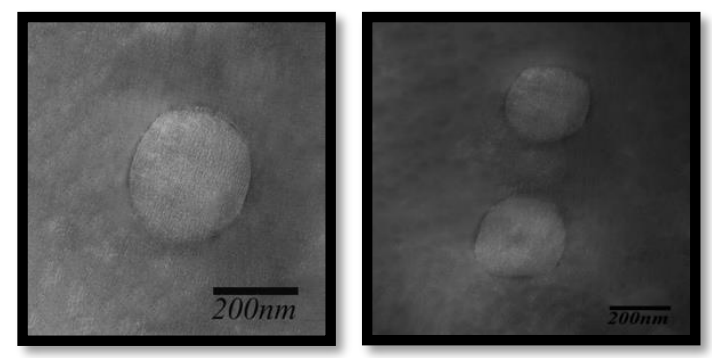

Gambar 1. Citra TEM Etosom Ekstrak Lamun

\section{Pembuatan Gel Sediaan}

Tahap pertama dari formulasi gel adalah optimasi jumlah Na CMC yang dibutuhkan. Penentuan tingkat rendah dan tinggi dari konsentrasi $\mathrm{Na} \mathrm{CMC}$ dengan mengamati respons sifat fisik yakni viskositas dan daya sebar yang dihasilkan dari sediaan gel yang diformulasi memenuhi kriteria penerimaan atau tidak. Pada Tabel 8 ditunjukkan data viskositas dan daya sebar hasil dari pengamatan yang dilakukan.

Tabel 8. Hasil rata-rata viskositas dan daya sebar sediaan gel

\begin{tabular}{ccc}
\hline $\begin{array}{c}\text { Konsentrasi } \\
\text { Na-CMC }\end{array}$ & $\begin{array}{c}\text { Viskositas } \\
\text { (Pa.s) }\end{array}$ & $\begin{array}{c}\text { Daya } \\
\text { sebar } \\
(\mathbf{c m})\end{array}$ \\
\hline $7 \%$ & 64,986 & 4,50 \\
$5 \%$ & 53,945 & 4,90 \\
$2,5 \%$ & 31,677 & 5,30 \\
$1 \%$ & 25,832 & 7,30 \\
\hline
\end{tabular}

Tabel 9. Formulasi sediaan gel etosom ekstrak tanaman lamun

\begin{tabular}{cc}
\hline \multirow{2}{*}{ Komposisi } & Jumlah $(\%)$ \\
\cline { 2 - 2 } & Formula \\
\hline Etosom ekstrak & 10 \\
Tanaman Lamun & 1 \\
Na CMC & 5 \\
Gliserin & 0,1 \\
Phenoxyethanol & 2,5 \\
Propilenglikol & 2 tetes \\
Parfum & ad 100 \\
Aqua DM & \\
\hline
\end{tabular}

Pada Tabel 8 menunjukkan bahwa pada konsentrasi $\mathrm{Na}-\mathrm{CMC} 7 \%$; 5\%; 2,5\%; dan $1 \%$ respons yang diperoleh masuk dalam kriteria penerimaan viskositas, namun pada penelitian ini peneliti memilih Na-CMC dengan konsentrasi $1 \%$ dengan nilai visikositas 25,832 Pa.s dengan daya sebar 7,30 cm.

Setelah didapatkan konsentrasi CMC yang terbaik dilanjutkan dengan memformulasi sediaan gel etosom ekstrak lamun, hasil formulasi disajikan pada Tabel 9.

\section{Pengujian Stabilitas Fisik Sediaan Pelembab Gel}

\section{- Uji Organoleptik}

Dari hasil evaluasi bahwa gel etosom ekstrak tanaman lamun memiliki penampilan dengan warna putih kuning kehijauan yang jernih, berbentuk gel semisolid dan memiliki aroma parfum jeruk nipis. Warna kuning kehijauan pada formula gel dikarenakan etosom ekstrak tanaman lamun yang memiliki warna dasar kuning kehijauan. Penambahan gelling agent dengan konsentrasi $1 \%$ membuat sediaan ini cair sedikit kental.

\section{- Uji Daya Sebar Gel}

Uji daya sebar pada penelitian ini dilakukan untuk memastikan sediaan gel tersebar merata diarea kulit yang diaplikasikan pada saat penggunaan. Nilai daya sebar yang baik dan dapat diterima pada saat pengaplikasian yaitu pada rentang 5-7 cm. Semakin besar daya sebar yang diberikan, maka semakin besar kemampuan daya sebar zat aktif dan semakin luas kontak antara sediaan dengan kulit. Sediaan gel etosom ekstrak tanaman lamun memiliki nilai daya sebar antara $6.5-7.0 \mathrm{~cm}$.

\section{- Uji Viskositas Gel}

Pengukuran viskositas menggunakan alat viskometer Lamy Rheology digital menggunakan spindle Nomor 5 yang memiliki kecepatan $50 \mathrm{rpm}$, hasil visikositas sediaan gel disajikan pada Tabel 10 .

\section{- Uji pH Gel}

Rentang persyaratan $\mathrm{pH}$ untuk kulit yaitu 4,56,5. Dari Tabel 11 hasil pengukuran $\mathrm{pH}$ diketahui bahwa sediaan gel yang dihasilkan memiliki rentang $\mathrm{pH}$ 5,80-5,38. $\mathrm{pH}$ sediaan ini masih dalam 
rentang $\mathrm{pH}$ yang diperbolehkan penggunaannya di kulit.

Tabel 10. Evaluasi Visikositas Sediaan Gel Etosom Ekstrak Tanaman Lamun

\begin{tabular}{|c|c|c|}
\hline $\begin{array}{c}\text { Suhu } \\
\text { Penyimpanan } \\
\left({ }^{\circ} \mathrm{C}\right)\end{array}$ & $\begin{array}{c}\text { Waktu } \\
\text { Penyimpanan } \\
\text { (Minggu) }\end{array}$ & $\begin{array}{c}\text { Rata-Rata } \\
\text { Viskositas } \\
\text { (cps) }\end{array}$ \\
\hline \multirow[t]{5}{*}{ \pm 4} & 0 & 2750,00 \\
\hline & 2 & 2750,00 \\
\hline & 4 & 2650,00 \\
\hline & 6 & 2550,00 \\
\hline & 8 & 2550,00 \\
\hline \multirow[t]{5}{*}{ $\pm 27-30$} & 0 & 2693,00 \\
\hline & 2 & 2690,00 \\
\hline & 4 & 2648,00 \\
\hline & 6 & 2550,00 \\
\hline & 8 & 2548,00 \\
\hline \multirow[t]{5}{*}{ \pm 40} & 0 & 2690,00 \\
\hline & 2 & 2690,00 \\
\hline & 4 & 2642,00 \\
\hline & 6 & 2550,00 \\
\hline & 8 & 2548,00 \\
\hline
\end{tabular}

- Uji Iritasi

Pengamatan uji iritasi dilakukan pada hewan coba kelinci jantan berdasarkan dua parameter, yaitu udema dan eritema. Kulit akan menunjukkan reaksi yang kecil atau bahkan tidak menunjukkan reaksi sama sekali pada saat kontak pertama dengan bahan. Namun dapat dilihat setelahnya dengan bahan iritan dalam waktu pengamatan 24, 48 dan 72 jam. Untuk eritema akan terlihat warna kemerahan pada area kulit dan bentuk luka yang tampak (jika ada). Sedangkan udema akan terlihat apabila ada pembengkakan jika dibandingkan dengan kulit yang normal.

Pengujian yang dilakukan pada hewan uji kelinci menunjukkan bahwa semua kelinci yang telah diaplikasikan sediaan pada area punggung memberikan hasil negatif terhadap sediaan gel etosom ekstrak lamun yang diaplikasikan. Hasil uji iritasi disajikan pada Tabel 12.

Tabel 11. Hasil Pengukuran $\mathrm{pH}$ Sediaan Gel Etosom Ekstrak Lamun

\begin{tabular}{ccc}
\hline $\begin{array}{c}\text { Suhu Penyimpanan } \\
\left({ }^{\circ} \mathbf{C}\right)\end{array}$ & Minggu & Nilai $\mathbf{~ H ~}$ \\
\hline $\mathbf{\pm 4}$ & 0 & 5,80 \\
& 2 & 5,80 \\
& 4 & 5,70 \\
& 6 & 5,70 \\
& 8 & 5,60 \\
\hline $\mathbf{2 7}-\mathbf{3 0}$ & 0 & 5,70 \\
& 2 & 5,60 \\
& 4 & 5,53 \\
& 6 & 5,47 \\
& 8 & 5,38 \\
\hline $\mathbf{4 0}$ & 0 & 5,80 \\
& 2 & 5,80 \\
& 4 & 5,70 \\
& 6 & 5,70 \\
& 8 & 5,60 \\
\hline
\end{tabular}

Uji aktivitas penghambatan enzim tirosinase Gel Etosom Ekstrak Lamun secara in vitro

Pada pengujian aktivitas inhibisi enzim, uji penghambatan aktivitas enzim tirosinase dilakukan terhadap gel etosom ekstrak tanaman lamun (E. acoroides) dan asam kojat sebagai pembanding secara in vitro menggunakan konsentrasi enzim $310 \mathrm{U} / \mathrm{mL}$, pH 6,8, waktu inkubasi 30 menit, konsentrasi substrat $10 \mathrm{mM}$ dan suhu $37^{\circ} \mathrm{C}$. Pengujian secara in vitro dipilih karena bahan-bahan yang digunakan pada pengujian ini mudah diperoleh, tidak membutuhkan waktu yang lama dan sederhana. Hasil uji aktivitas penghambatan enzim tirosinase disajikan dalam Tabel 13. 
Tabel 12. Hasil pengamatan uji iritasi pada hewan kelinci

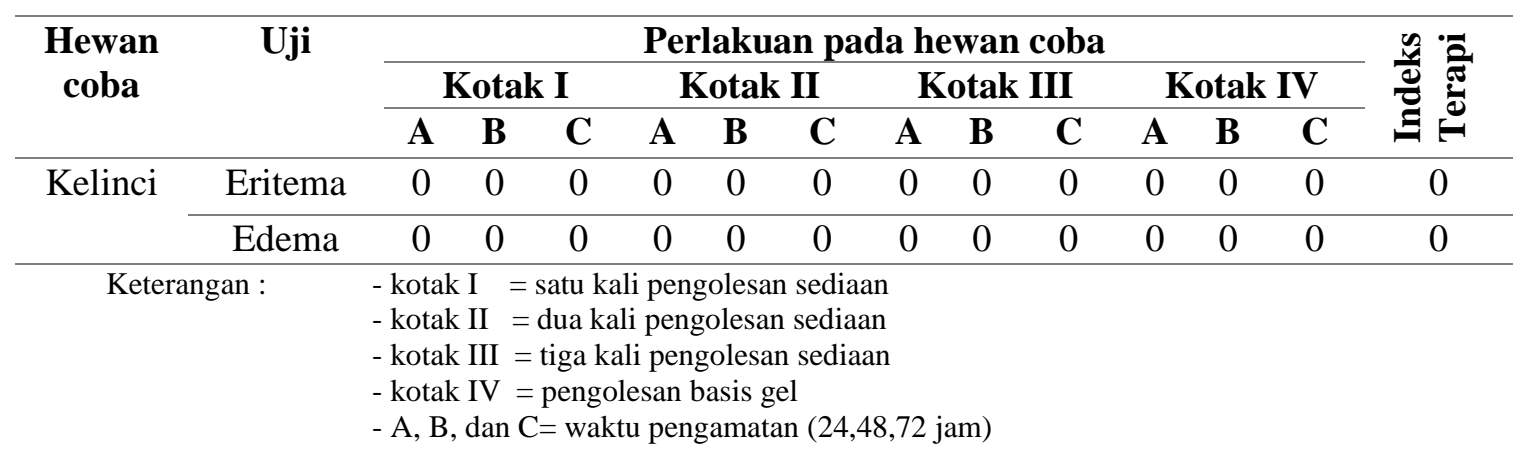

Tabel 13. Hasil uji aktivitas inhibisi enzim tirosinase terhadap gel etosom ekstrak lamun

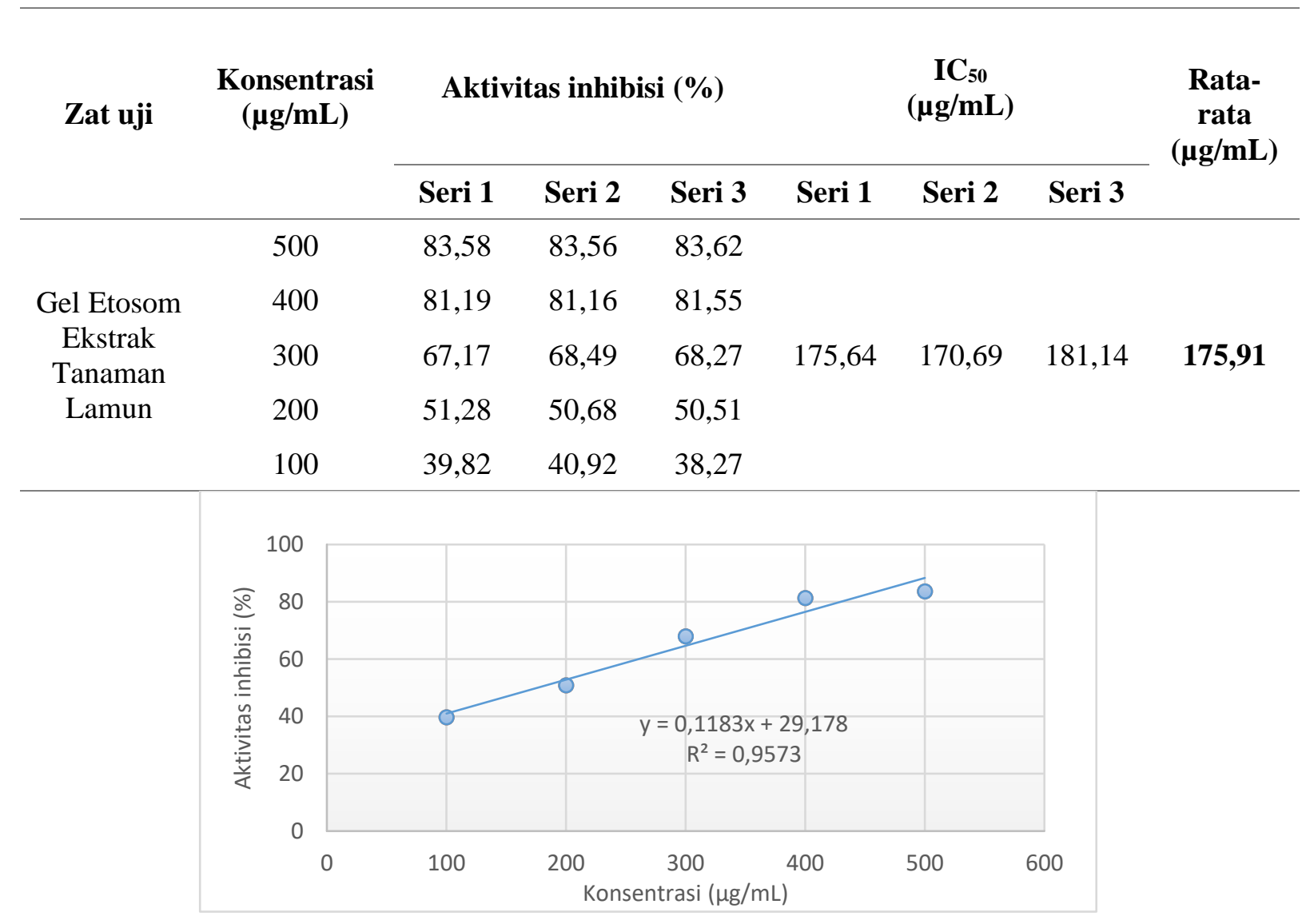

Gambar 2. Grafik Hasil uji aktivitas inhibisi enzim tirosinase terhadap gel etosom ekstrak lamun

Hasil pengukuran aktivitas inhibisi enzim tirosinase dari Gel Etosom Ekstrak lamun menunjukkan bahwa sediaan gel memiliki aktivitas inhibisi dengan $\mathrm{IC}_{50} \quad 175,91 \mu \mathrm{g} / \mathrm{mL}$, dibandingkan dengan asam kojat $(11,318 \mu \mathrm{g} / \mathrm{mL})$ yang umumnya digunakan sebagai inhibitor standar untuk uji aktivitas tirosinase. Nilai $\mathrm{IC}_{50}$ dipengaruhi oleh ukuran partikel yang dihasilkan dari formula sediaan yang diuji, ukuran partikel yang terkecil menghasilkan nilai $\mathrm{IC}_{50}$ yang terkecil juga, hal ini menunjukkan bahwa semakin kecil ukuran partikel maka memiliki penetrasi yang semakin baik dan dengan konsentrasi kecil sudah dapat menghambat aktivitas enzim tirosinase.

\section{Uji efektivitas Pelembab}

Pengujian kelembaban pada kulit dilakukan selama satu bulan dengan menggunakan alat skin analyzer-moisture checker mode (SK-8), yang 
mana alat ini dapat memberikan informasi nilai kadar air pada kulit. Sebelum sediaan gel digunakan pada area kulit, dilakukan pengukuran kelembaban terlebih dahulu pada area lengan relawan. Hasil dari pengukuran kelembaban kulit terhadap relawan menunjukkan bahwa sediaan gel etosom ekstrak tanaman lamun memiliki kemampuan dan manfaat untuk meningkatkan kelembaban diarea kulit lengan dengan persentase yang berbeda-beda. Pengujian juga dilakukan pada sediaan blangko, yaitu basis gel tanpa etosom ekstrak lamun. Sediaan blangko menunjukkan hasil peningkatan kelembaban yaitu sebesar $0,3 \%$ selama waktu pengujian. Sediaan Gel etosom ekstrak tanaman lamun memiliki kemampuan melembapkan kulit sebesar $1,7 \%$ selama pengujian.
Hasil pengukuran nilai kelembaban kulit yang dilakukan terhadap 18 sukarelawan dapat dilihat pada Tabel 14 dan 15, hasil persentase peningkatan kelembaban kulit dapat dilihat pada Tabel 16 dan 17.

Persentase peningkatan kelembaban kulit selama pemakaian sediaan gel disajikan pada Tabel 17 Semua sediaan gel yang dibuat memiliki persentase peningkatan kemampuan melembapkan yang berbeda-beda. Sediaan gel tanpa etosom ekstrak lamun memiliki kemampuan untuk meningkatkan kelembaban kulit yang lebih baik yaitu peningkatan rata-rata di hari ke-28 sebesar $0,3 \%$. Sediaan gel etosom ekstrak tanaman lamun memiliki kemampuan melembapkan kulit sebesar $0,6 \%$ pada hari ke-14 dan meningkat sebesar $1,7 \%$ pada pengujian hari ke 28 .

Tabel 14. Hasil pengukuran kelembaban pada sebelum dan setelah pemakaian Basis Gel hari 14 dan 28

\begin{tabular}{|c|c|c|c|c|c|c|c|c|c|c|c|c|c|c|c|c|c|c|c|}
\hline \multirow{2}{*}{$\begin{array}{c}\text { Basis } \\
\text { Gel }\end{array}$} & \multicolumn{18}{|c|}{ Relawan } & \multirow{2}{*}{ } \\
\hline & 1 & 2 & 3 & 4 & 5 & 6 & 7 & 8 & 9 & 10 & 11 & 12 & 13 & 14 & 15 & 16 & 17 & 18 & \\
\hline $\begin{array}{c}\text { Awal } \\
(\%)\end{array}$ & 35,7 & 36,2 & 35,5 & 35,4 & 35,7 & 39,6 & 38,4 & 35,5 & 34,8 & 38,6 & 38,2 & 37,0 & 35,0 & 35,7 & 36,2 & 39,0 & 35,7 & 38,6 & 36,3 \\
\hline $\begin{array}{c}\text { Hari ke } \\
14\end{array}$ & 35,8 & 36,5 & 35,8 & 36,0 & 36,0 & 40,3 & 38,7 & 35,5 & 34,8 & 38,5 & 38,5 & 37,0 & 35,2 & 35,7 & 36,3 & 38,7 & 35,9 & 39,0 & 36,5 \\
\hline $\begin{array}{c}\text { Hari ke } \\
28\end{array}$ & 36,0 & 36,7 & 36,0 & 36,0 & 36,0 & 40,5 & 39,0 & 35,5 & 34,8 & 38,5 & 38,5 & 37,3 & 35,5 & 35,7 & 36,3 & 38,7 & 35,9 & 39,4 & 36,7 \\
\hline
\end{tabular}

Tabel 15. Hasil pengukuran kelembaban pada sebelum dan setelah pemakaian Gel Etosom Ekstrak Lamun hari 14 dan 28

\begin{tabular}{|c|c|c|c|c|c|c|c|c|c|c|c|c|c|c|c|c|c|c|c|}
\hline \multirow{2}{*}{$\begin{array}{c}\text { Gel } \\
\text { Etosom } \\
\text { Ekstrak } \\
\text { Lamun }\end{array}$} & \multicolumn{18}{|c|}{ Relawan } & \multirow{2}{*}{ 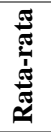 } \\
\hline & 1 & 2 & 3 & 4 & 5 & 6 & 7 & 8 & 9 & 10 & 11 & 12 & 13 & 14 & 15 & 16 & 17 & 18 & \\
\hline Awal (\%) & 35,7 & 36,2 & 35,5 & 35,4 & 35,7 & 39,6 & 38,4 & 35,5 & 34,8 & 38,6 & 38,2 & 37,0 & 35,0 & 35,7 & 36,2 & 39,0 & 35,7 & 38,6 & 36,3 \\
\hline $\begin{array}{c}\text { Hari ke } \\
14\end{array}$ & 36,4 & 37,5 & 36,3 & 36,4 & 36,2 & 40,6 & 38,8 & 35,9 & 35,0 & 38,8 & 39,0 & 37,5 & 35,6 & 35,9 & 36,8 & 38,8 & 36,5 & 39,8 & 36,8 \\
\hline Hari ke & 37,0 & 38,7 & 38,0 & 37,0 & 36,8 & 41,2 & 40,0 & 37,5 & 36,8 & 39,6 & 39,5 & 38,4 & 36,5 & 36,9 & 38,3 & 39,8 & 38,2 & 41,4 & 38,06 \\
\hline
\end{tabular}

Adapun analisa statistik menunjukkan bahwa gel etosom ekstrak lamun memiliki nilai yang tidak signifikan dalam hal meningkatkan kelembaban kulit jika dibandingkan dengan gel tanpa etosom ekstrak lamun, Dengan demikian dapat diartikan bahwa sediaan gel etosom ekstrak lamun mampu meningkatkan kelembaban kulit dan membuat kulit kategori kering menjadi kulit kategori normal.

Nilai persentase yang dihasilkan terhadap kemampuan mengurangi penguapan air dari kulit berbeda untuk setiap panelis dikarenakan berbedanya cuaca pada saat melakukan pengujian serta banyaknya keringat yang dihasilkan oleh masing-masing panelis tidak sama, Penyebab lainnya adalah kemungkinan aktivitas yang dilakukan oleh panelis juga berbeda-beda.

\section{Kesimpulan}

Tanaman Lamun yang diperoleh dari perairan Kepulauan Riau (Batam) dengan spesies Enhalus acoroides setelah dimaserasi didapatkan hasil rendemen ekstrak sebanyak $21,45 \%$, dengan kandungan total fenol $22,04 \%$ dan total flavonoid $5,76 \%$, Ekstrak etanol tanaman lamun dapat dibuat menjadi etosom dengan karakterisasi ukuran partikel 216,1 $\mathrm{nm}$ dengan nilai indeks polidispersitas yaitu $24,97 \%$, serta nilai zeta potensial -19,23 $m V$, Gel etosom ekstrak lamun 
dapat menginhibisi enzim tyrosinase dengan nilai $\mathrm{IC}_{50} 175,91 \mu \mathrm{g} / \mathrm{mL}$.

\section{Ucapan Terima Kasih}

Terima kasih diucapkan atas dukungan Dekan Fakultas Farmasi Universitas Pancasila beserta jajarannya sehingga penelitian kami ini dapat terlaksana dengan lancar dan baik.

\section{Referensi}

[1] Tangke U, Ekosistem padang lamun (Manfaat, Fungsi dan Rehabilitasi), Agrikan J Agribisnis Perikan [Internet], 2010;3(1):9, Available from: http://dx,doi,org/10,29239/j,agrikan,3,1,929

[2] Riniatsih I, Setyati WA, Bioaktivitas Ekstrak dan Serbuk Lamun Enhalus acoroides dan Thalassia hemprichii pada Vibrio alginolyticus dan Vibrio harveyii, Indones J Mar Sci, 2012;14(3):138-41.

[3] Kannan RRR, Arumugam R, Anantharaman $\mathrm{P}$, In vitro antioxidant activities of ethanol extract from Enhalus acoroides (L,F,) Royle, Asian Pac J Trop Med [Internet], 2010;3(11):898-901, Available from: http://dx,doi,org/10,1016/s19957645(10)60216-7

[4] Wakano D, Seagrass Enhalus acoroides Fruit Utilization as Alternative Food Sources Lomin Village Community East of Seram, In: Prosiding FMIPA Universitas Pattimura 2013, Ambon: Universitas Pattimura; 2013, p, 10-2.

[5] Qi S-H, Zhang S, Qian P-Y, Wang B-G, Antifeedant, antibacterial, and antilarval compounds from the South China Sea seagrass Enhalus acoroides, Bot Mar [Internet], 2008;51(5), Available from: http://dx,doi,org/10,1515/bot,2008,054

[6] Thassu D, Pathak Y, Deleers M, Nanoparticulate Drug-Delivery Systems: An Overview [Internet], Nanoparticulate Drug Delivery Systems, CRC Press; 2007, $\mathrm{p}, \quad 1-31, \quad$ Available from: http://dx,doi,org/10,1201/97814200084491

[7] Berth-Jones J, Topical Therapy [Internet], Rook's Textbook of Dermatology, WileyBlackwell; 2010, p, 1-52, Available from: http://dx,doi,org/10,1002/9781444317633, $\operatorname{ch} 73$

[8] R V, Buku Pengantar Teknologi Farmasi, Yogyakarta, Univ Gadjah Mada Press, 1994

[9] Blainski A, Lopes G, de Mello J, Application and Analysis of the Folin Ciocalteu Method for the Determination of the Total Phenolic Content from Limonium Brasiliense L, Molecules [Internet], 2013;18(6):6852-65, Available from: http://dx,doi,org/10,3390/molecules 180668 52

[10] Akiladevi D, Basak S, Ethosomes -- a Noninvasive Approach for Transdermal Drug Delivery, Int J Curr Pharm Res, 2010;2(4):2-5.

[11] Anief M, Ilmu Meracik Obat: Teori dan Praktik, Yogyakarta: Gadjah Mada University Press; 1997.

[12] Astuti DP, Husni P, Hartono K, Formulasi dan Uji Stabilitas Fisik Sediaan Gel Antiseptik Tangan Minyak Atsiri Bunga Lavender (Lavandula angustifolia Miller), Farmaka, 2017;15(1):176-84.

[13] Ditjen POM DR, Parameter standar umum ekstrak tumbuhan obat, Jakarta: Departement Kesehatan Republik Indonesia, Ed IV, 2000. 